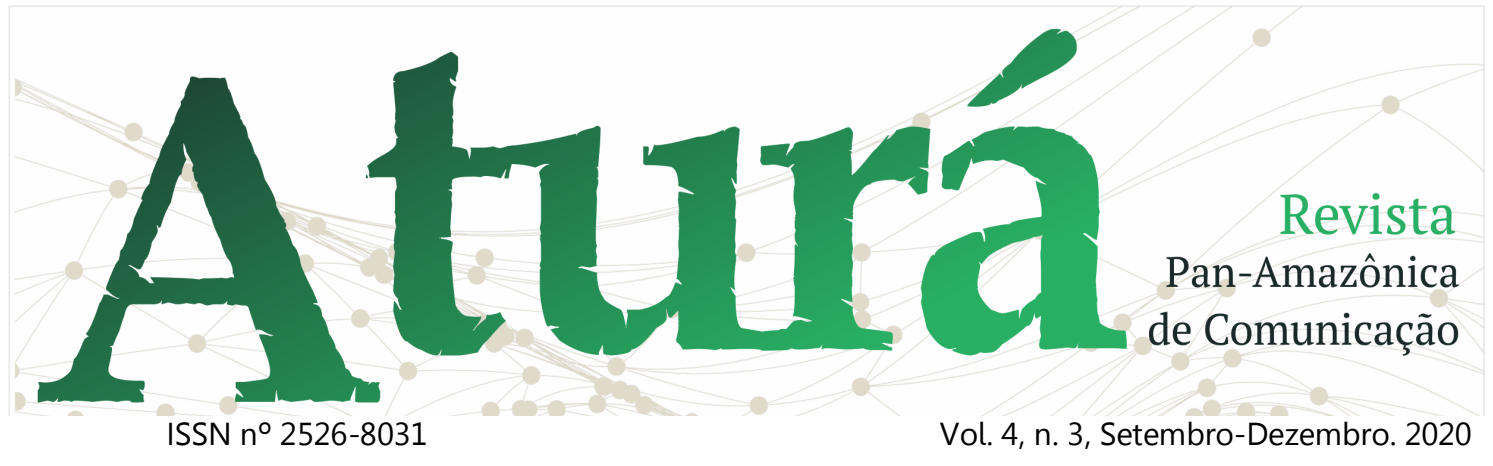

\title{
O CASO DO ÔNIBUS 174: UM ESTUDO DE RECEPÇÃO
}

The case of bus 174: a reception study

El caso del bus 174: un estudio de recepción

\section{Fábio Cruz ${ }^{1}$}

Estevan de Freitas Garcia²

\section{RESUMO}

Neste trabalho, é apresentado um estudo de recepção sobre a reportagem veiculada no telejornal Jornal Nacional (JN) sobre o caso do ônibus 174. Os objetivos, de forma geral, resumem-se em observar as percepções dos entrevistados sobre o caso a partir da matéria do JN e, em seguida, observar se a contextualização do assunto (a partir da utilização de trechos do documentário Ônibus 174, de José Padilha) mudaou não as percepções do receptor. A fim de evidenciar o objeto, é abordada uma perspectiva histórica da Rede Globo de Televisão e do Jornal Nacional. Quanto aos aportes teórico-metodológicos, adotou-se os pressupostos das multimediações de Orozco Gómez (2000). Como resultado, destacou-se a insatisfação da maioria dos entrevistados com a produção, além de uma mudança nas perspectivas apontadas a partir da contextualização do caso.

PALAVRA-CHAVE: Ônibus 174; Recepção; Telejornalismo.

\section{ABSTRACT \\ In this paper, a reception study is presented on the report broadcast on the news program Jornal Nacional (JN) about the case of the 174 bus. The objectives, in general, are summarized in observing the perceptions of the interviewees about the case from the matter do $\mathrm{JN}$ and then observe whether the contextualization of the subject (based on excerpts from the documentary Ônibus 174, by José Padilha) did not change the receiver's perceptions. In order to highlight the object, a historical perspective of Rede Globo de

\footnotetext{
${ }^{1}$ Universidade Federal de Pelotas. E-mail: fabiosouzadacruz@gmail.com.

2 Bacharel em Jornalismo pela Universidade Federal de Pelotas (UFPel) e mestre pelo Programa de PósGraduação em Sociologia (PPGS/UFPel). Tem experiência nas áreas de assessoria de comunicação e webjornalismo. E-mail: estevanfreitasg@gmail.com.
} 


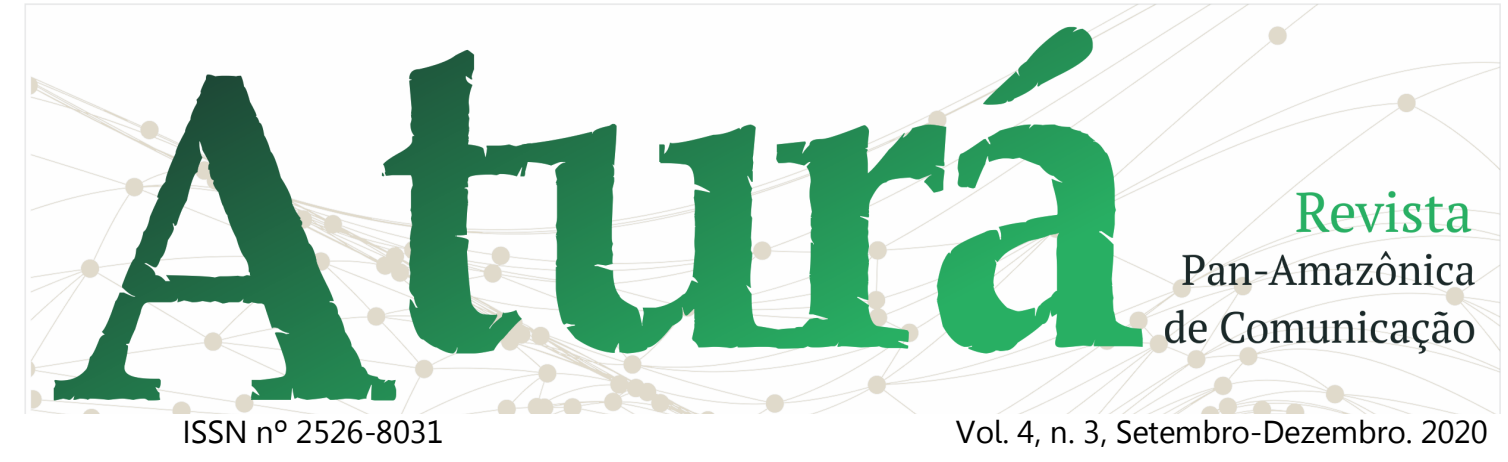

Televisão and Jornal Nacional is approached. As for the theoretical-methodological contributions, the assumptions of multimediations by Orozco Gómez (2000) were adopted. As a result, the dissatisfaction of the majority of respondents with the production stood out, in addition to a change in the perspectives pointed out from the context of the case.

KEYWORD: Bus 174; Reception; Television Journalism.

\section{RESUMEN}

En este trabajo se presenta un estudio de recepción del reportaje emitido en el noticiero Jornal Nacional (JN) sobre el caso del bus 174. Luego se observa si la contextualización del tema (a partir de extractos del documental Ônibus 174, por José Padilha) no cambió la percepción del receptor. Para resaltar el objeto, se aborda una perspectiva histórica de la Rede Globo de Televisão y Jornal Nacional. En cuanto a los aportes teórico-metodológicos, se adoptaron los supuestos de multimedia de Orozco Gómez (2000). Como resultado, se destacó el descontento de la mayoría de los entrevistados con la producción, además de un cambio en las perspectivas señaladas desde el contexto del caso.

PALABRAS CLAVE: Bus 174; Recepción; Periodismo televisivo. 


\section{A \\ ISSN n' 2526-8031 \\ Vol. 4, n. 3, Setembro-Dezembro. 2020}

\section{Introdução}

Apesar de ter feito o pedido de concessão um ano após a TV ter sido trazida para o Brasil, A Rede Globo obteve sua inauguração, de fato, em 26 de abril de 1965. Deste dia em diante, a Rede Globo ganhava o direito a fazer uso do canal 4, no Rio de Janeiro. Em pouco tempo o negócio se expande. Sua programação, a qual tinha por base 0 entretenimento, levando as novelas como principal produto, começa a ser distribuída para outros estados por meio de emissoras próprias e de afiliadas. É a TV Globo quem consolida, em 1975, o conceito de rede, exibindo sua programação simultaneamente para todo Brasil.

Com o passar dos anos, a TV Globo foi a que mais se desenvolveu tecnicamente. Hoje, "com cinco emissoras próprias, de propriedade da Família Marinho, e 118 afiliadas no Brasil, pertencentes a diversos grupos empresariais, o sinal da Rede Globo chega atualmente a 5.490 municípios brasileiros"3.

No ano de 1969, a Rede Globo lança o Jornal Nacional, primeiro telejornal em rede transmitido via Embratel. "Com o conceito de noticiário que desperta o interesse de todos os brasileiros, o Jornal Nacional inova no formato e na linguagem ${ }^{4 \prime}$. Além disso, conforme Rezende (2000), destaca-se o alto custo e capricho do programa. "Os objetivos reais que motivavam a iniciativa ligavam-se a interesses políticos e mercadológicos. Além de possuir um noticiário que lhe desse prestígio, a TV Globo queria competir com o Repórter Esso, da TV Tupi" (REZENDE, 2000, p. 109). O telejornal é pioneiro com as participações ao vivo dos locais dos acontecimentos, a fim de dar precisão e credibilidade à notícia. "O Jornal Nacional busca a isenção, correção e agilidade

\footnotetext{
${ }^{3}$ Disponível em

<http://historiagrupoglobo.globo.com/hgg/index.htm> . Acesso em 28 fev 2017

${ }^{4}$ Disponível em

<http://historiagrupoglobo.globo.com/hgg/index.htm> . Acesso em 28 fev 2017
} 


\section{A \\ ISSN n² 2526-8031 \\ Vol. 4, n. 3, Setembro-Dezembro. 2020}

como atributos da informação de qualidade ${ }^{5 "}$.

No entanto, apesar do slogan que fala em informação de qualidade, autores como Rezende (2000) apontam para a superficialidade do noticiário desde seu surgimento. Essa superficialidade seria resultado de uma diretriz editorial baseada na agilidade do estilo "manchetado", que se ajustava ao perfil da audiência do programa. (REZENDE, 2000, p.116). Ainda conforme Rezende (2000), essas características permaneceriam (até o ano de publicação do livro) vigentes no jornal. $O$ que se observa, atualmente, ainda são matérias com pouca rápidas, "ágeis" e com pouca profundidade.

\section{0 caso do Ônibus 174}

12 de junho de 2000, 14h20min. 0 ônibus da linha 174 (Central-Gávea) é interceptado pela polícia após um dos passageiros ter sinalizado para um carro da PM que um dos demais passageiros estaria portando uma arma. $\mathrm{O}$ ônibus fica

\footnotetext{
${ }^{5}$ Disponível em

<http://historiagrupoglobo.globo.com/hgg/index.htm> . Acesso em 28 fev 2017.
}

detido no Bairro Jardim Botânico sob a mira do passageiro que portava a arma. $\mathrm{O}$ revólver, calibre 38, era de Sandro Barbosa do Nascimento, 21 anos.

Embora o motorista, o cobrador e vários passageiros tenham conseguido fugir após anunciado o sequestro, cerca de 10 pessoas foram mantidas no ônibus como reféns. O reforço da Polícia Militar e do BOPE chega em seguida, dando início às negociações.

Durante o sequestro, Sandro liberou o estudanteWilliam Nunes de Moura, afirmando que este deveria estar atrasado para sua aula. Em seguida liberou Damiana Nascimento de Souza, a qual afirmou a Sandro que teria um irmão - qual teria passado pelas mesmas dificuldades que Sandro na prisão.

A presença da imprensa no local, de início, incomodou Sandro, que se queixou para a polícia, pedindo para que os fotógrafos e cinegrafistas fossem retirados do local. No entanto, com o passar das horas, Sandro começa a falar com as câmeras.

Após quase cinco horas de tensão, às $18 \mathrm{~h} 47 \mathrm{~min}$ Sandro desce do ônibus 


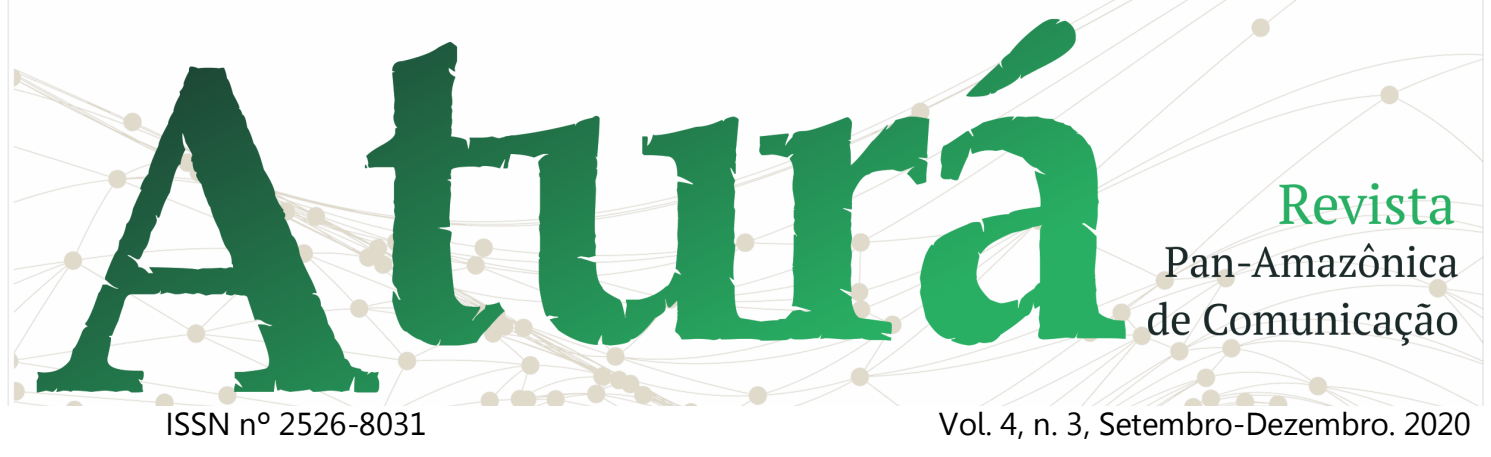

abraçado à professora Geisa Gonçalves, apontando a arma para a refém. Um dos policiais do BOPEse aproxima por trás do ônibus e dispara contra Sandro, errando os dois tiros. Um dos tiros acerta de raspão o queixo de Geisa. Sandro cai, disparando três vezes contra a refém. A população invade o cerco policial a fim de linchar Sandro, o que é evitado pela polícia. Geisa morre no caminho para o hospital. Sandro morre, segundo as informações oficiais, asfixiado no camburão da polícia.

\section{A vida do sequestrador 6}

Para tratar do caso do ônibus 174, julgamos necessário contar um pouco da vida do protagonista do caso: Sandro Barbosa do Nascimento, o sequestrador. Conforme informações trazidas pelo documentário Ônibus 174, de José Padilha, Sandro nasceu em uma região próxima a Niterói, Rio de Janeiro (RJ). Já aos 6 anos, viu a mãe Clarice Rosa do Nascimento ser assassinada a facadas em

${ }^{6}$ Informações retiradas dos relatos dos entrevistados (muitos deles familiares de Sandro e pessoas próximas) do documentário Ônibus 174, de José Padilha.

frente ao seu próprio bar, localizado na favela do Rato Molhado, RJ.

Após a morte da mãe Sandro fica na responsabilidade da tia materna. No entanto, logo em seguida foge e vira morador de rua. Envolve-se em assaltos e consumo de drogas durante a infância e adolescência. Passa por internatos de menores infratores e é preso, vivendo a realidade sub-humana dos presídios brasileiros. Foi testemunha ocular e sobrevivente do Massacre da Candelária chacina ocorrida em 23 de julho de 1993, próximo à Igreja da Candelária, centro do Rio de Janeiro, na qual oito jovens em situação de rua foram assassinados por policiais militares ${ }^{7}$.

\section{A matéria do Jornal Nacional sobre o caso do ônibus 174}

No mesmo dia do acontecimento do caso do ônibus 174, 12 de junho, o Jornal Nacional levou ao ar uma matéria de três minutos e quatorze segundos sobre o caso. Após o típico "Boa noite!", a

\footnotetext{
7 Disponível em <

http://memoriaglobo.globo.com/programas/jornalismo /coberturas/chacina-na-candelaria/jornal-nacionalsobre-a-chacina.htm >. Acesso em 01 maio 2019
} 


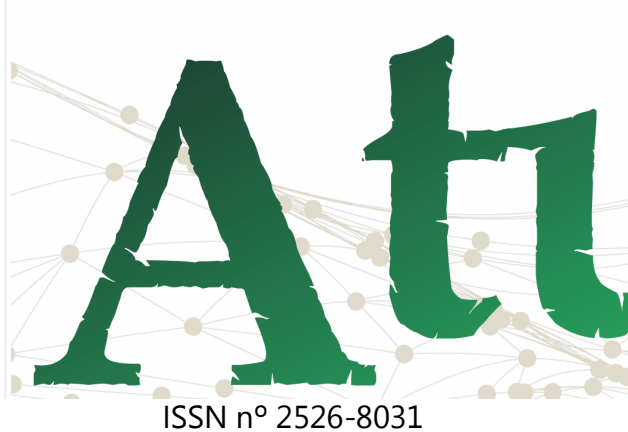

ISSN n² 2526-8031

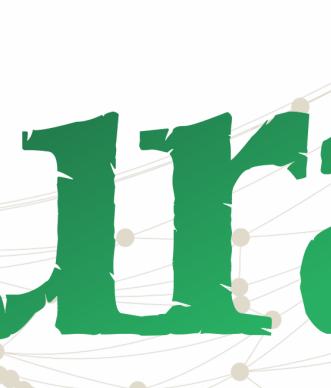

Vol. 4, n. 3, Setembro-Dezembro. 2020 frase de chamada de Fátima Bernardes, na época âncora do jornal, já define o que será mostrado durante a matéria: "Desespero e morte na zona sul do Rio de Janeiro. Um homem armado sequestrou um ônibus no bairro do Jardim Botânico". Em seguida, começam a ser passadas imagens do ônibus, dos policiais e flashs do sequestrador, com a voz do repórter de fundo contando: "O drama dos passageiros desse ônibus começou pouco antes das três horas da tarde. Um assaltante armado com um revólver ameaça quem chega por perto. Ele não se entrega apesar dos apelos da polícia que cercou o ônibus. Agarrado com uma passageira, o assaltante aponta a arma para todos os lados".

Em seguida, o repórter, com uma postura nervosa, faz a passagem contanto: "O assaltante agora está tentando sair com o ônibus, com a vítima no colo dele". Em seguida voltam as imagens do ônibus, as quais mostram o "assaltante", como é colocado na matéria, sentado no banco do motorista, com uma passageira no seu colo, e outro refém do seu lado, mexendo na direção. O repórter fala que "o criminoso ainda obriga o passageiro a ajudá-lo, mas os dois não conseguem fazer $\mathrm{o}$ ônibus andar. Nervoso, ele segura a mulher e atira em direção aos policiais. Ele continua ameaçando os reféns". Em seguida, as imagens mostradas são as de uma das reféns escrevendo no vidro do ônibus, e o repórter continua: "uma das vítimas é obrigada a escrever com um batom no vidro do ônibus que o assaltante está possuído pelo diabo".

$\mathrm{Na}$ sequência, é mostrado o momento em que um dos reféns sai pela janela do ônibus e imagens do bandido. O repórter narra: "Só depois de uma hora o refém é libertado. Mas a negociação não avança, o bandido quer duas granadas e duas pistolas. A polícia não cede". Em seguida, as imagens de uma passageira saindo do ônibus ganha a tela e a narração continua: "Ele solta mais uma passageira". Após isso, a reportagem mostra novamente imagens do ônibus. $O$ repórter conta: "Pouco antes das seis horas o assaltante atira para o chão". O somdo tiro sendo dado e de gritos dentro do ônibus ganha destaque. Em seguida, o 


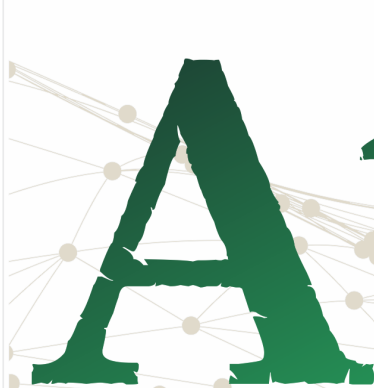

ISSN n² 2526-8031

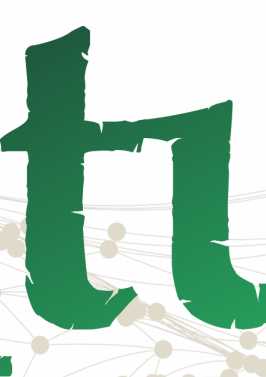

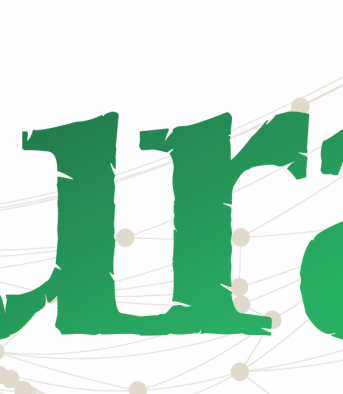

Vol. 4, n. 3, Setembro-Dezembro. 2020 outro apresentador, Willian Bonner, aparece. Logo atrás do apresentador, o plano de fundo do cenário se destaca: em tons de vermelho, com a figura de uma pessoa com uma arma apontada. Bonner prossegue: "Os tiros aumentaram ainda mais o pânico entre os reféns que estavam dentro do ônibus". As imagens do ônibus voltam, dando destaque para as reféns gritando.

O repórter continua: "Depois do tiro, o desespero. O bandido não desistiu. Pegou outra refém. Ameaçou atirar de novo. Pôs o revolver na boca da mulher. Puxou os cabelos dela e desafiou os policiais". Na sequência, as imagens do sequestrador aparecem na tela, e sua voz ganha destaque. No canto inferior da tela, a legenda deixa mais claro o que o assaltante diz: "Seu delegado, já morreu uma. Vai morrer outra". As imagens de dentro do ônibus retornam e o repórter prossegue: "Ele não atirou, mas fez novas ameaças", dando lugar as palavras do sequestrador, novamente com a legenda: "Não quero saber, vai morrer essa aqui agora, na tua frente". O repórter continua: "O bandido levou a refém para o fundo do ônibus e mandou que ela amarrasse um cordão no pescoço dele". E prossegue: "O primeiro prazo dado pelo bandido acabou às seis horas, mas os policiais o convenceram a continuar negociando". O repórter volta às telas na passagem contando: "Seis e meia. A negociação não deu resultado.

O bandido foi mais uma vez para a frente do ônibus junto com a refém. Ele deu um novo prazo para a polícia, quer que as exigências sejam aceitas até as sete e meia da noite. Se não, ameaça matar todos os reféns". As imagens de dentro do ônibus retornam à tela e a voz do repórter continua: "O bandido ameaçou atirar de novo. Voltou a andar pelo ônibus com a refém. Um passageiro de muletas foi retirado. A tensão aumentou. De repente, o bandido abriu a porta e desceu usando a refém de escudo". As imagens do bandido fora do ônibus, com um pano tapando o rosto e a refém em sua frente ganham a tela. $O$ repórter dá continuidade à narração: "Nesse momento, a polícia agiu. Um PM se aproximou pelo lado e deu dois tiros 


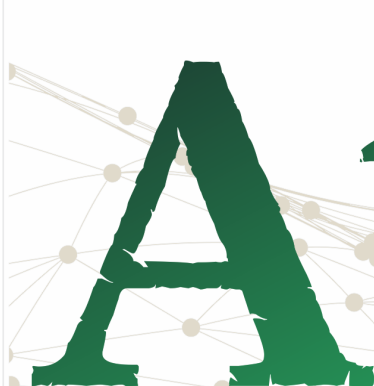

ISSN n² 2526-8031

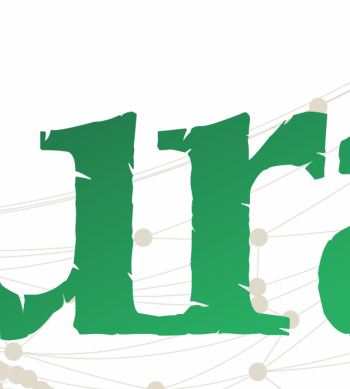

Vol. 4, n. 3, Setembro-Dezembro. 2020 no bandido". A imagem narrada toma a cena.

O áudio dá destaque para o som dos tiros e a narração continua: "Os policiais que estavam à distância avançaram". As cenas do ônibus voltam e o repórter conta: "No meio da confusão, a jovem que teria sido baleada se levantou. Estava viva". Imagens de furo de bala e de sangue tomam a cena e $\mathrm{O}$ repórter conclui: "O bandido e a refém que desceu do ônibus com ele foram levados para o hospital". Fátima Bernardes volta à tela finalizando a matéria: "A polícia informou que $\mathrm{o}$ bandido que sequestrou o ônibus morreu a caminho do hospital. Geisa Firmo Gonçalves, a refém que estava com ele no momento em que a polícia atirou, também morreu. Segundo a direção do hospital Miguel Couto, ela levou três tiros".

\section{Sobre recepção: o aporte teórico-} metodológico

Guillermo Orozco Gómez (2000) em "La investigación em comunicación desde la perspectiva cualitativa", coloca que, para entender um processo de comunicação, precisamos entender, além da emissão, a recepção. Desta forma, utilizamos a proposta metodológica do autor, a fim de fazer os estudos voltados à recepção.

Durante muito tempo, as pesquisas em comunicação foram focadas na produção. O receptor - conforme, por exemplo, a Teoria Hipodérmica, cunhada na Escola Norte-Americana, nos anos de 1930 - era tido como passivo, um mero recipiente, onde eram despejados os conteúdos midiáticos com resposta direta ao estímulo, sem negociação ne contestação. No entanto, a partir dos anos 70 , a concepção de receptor passivo dá lugar ao entendimento de um receptor ativo, o qual tem participação na criação de significados da mensagem. Desta forma, a fim de fazer uma análise voltada à recepção, nos guiaremos pelos pressupostos de Guillermo Orozco Gómez (2000), que traz uma proposta de estudo de recepção televisiva embasada numa pesquisa qualitativa.

$\mathrm{O}$ autor traz quatro paradigmas de produção do conhecimento, sendo eles o positivista, o realista, o hermenêutico e o 


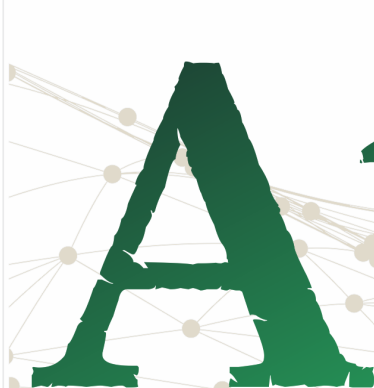

ISSN n $2526-8031$

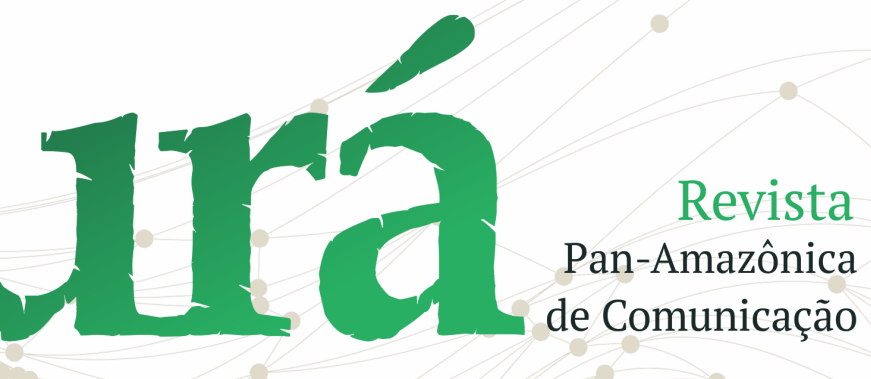

Vol. 4, n. 3, Setembro-Dezembro. 2020 interacionista. Devido ao fato da proposta do trabalho ser qualitativa, nos focaremos nos dois últimos paradigmas de produção e sentido citados por Orozco (2000), ou seja, o hermenêutico - onde se dá mais valor não ao que é, mas sim às interpretações do que é - e o interacionista - que investiga a conexão entre os elementos que podem estar influenciando na questão em foco.

Orozco (2000) aponta cinco ${ }^{8}$ correntes de investigação para 0 conhecimento da relação entre meios de comunicação e a audiência.Uma delas, que vem com $o$ intuito de entender a relação entre cultura, meios de comunicação e sociedade é a das mediações - a qual Orozco Gomez se filia. Conforme o autor, o conceito foi

\footnotetext{
8 Sendo elas a) Efeito dos meios: Se preocupa com a seguinte questão: "O que fazem os meios com a audiência?", ou "O que acontece com os receptores expostos a uma determinada mensagem?", . b) Usos e gratificações: Onde a pergunta se inverte - vendo o receptor como ativo - e fica focada no que fazem as pessoas com os meios. c) Criticismo literário: esta corrente faz um apanhado dos estudos sobre semiótica, temáticas sintáticas e correntes da estética da reflexão. Nesta, o que importa é ver o que se produz do contato entre o leitor e o texto. d) Corrente dos estudos culturais: A corrente dos estudos culturais, conforme Orozco (2000) nasce como produto das novas sociologias. Nesta, o que importa é o questionamento de qual é o papel da cultura na interação entre meio, mensagem e audiência. e) Das mediações, trabalhada no artigo.
}

inicialmente trazido por Manuel Martin Serrano e em seguida o termo foi aplicado por Jesús Martín Barbero em seu livro "Dos meios às mediações". Conforme cita Orozco (2000), a mediação, para Barbero, é o lugar onde se dá o sentido ao processo de comunicação. Desta forma, ele coloca a comunicação como a grande mediadora de todo processo de produção comunicativa. Para Barbero, as mediações de dividem em três: a) Socialidade: mediação que trata das práticas cotidianas. b) Ritualidade: se relaciona às rotinas, à repetição de atividades. c) Tecnicidade: que faz referência aos meios e às técnicas de comunicação.

A fim de levar a teorização de Barbero ao nível empírico, Orózco Gómez (2000) traz as Multi Mediações, as quais estão inseridas em um paradigma hermenêutico, e se dividem em cinco: a)Mediação Individual: a qual se refere à individualidade do sujeito cognocente e comunicativo;b) Mediação Institucional: a qual faz referência à relevância da família, escola, trabalho, igreja, etc, na criação das concepções das pessoas nas suas 


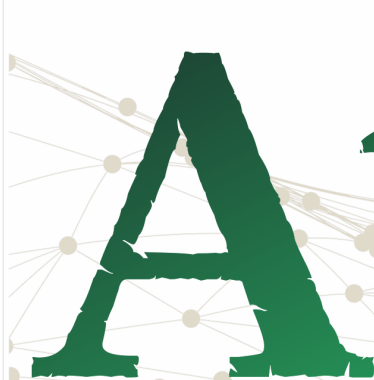

ISSN n²526-8031

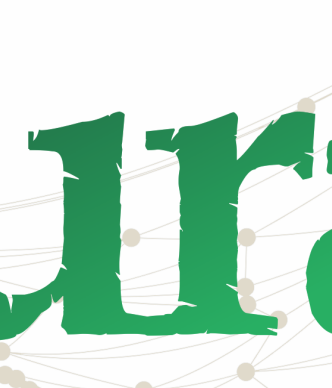

Vol. 4, n. 3, Setembro-Dezembro. 2020 interpretações de mundo; c) Mediação Massmídia ou videotécnológica: Esta traz a tecnologia exercendo uma mediação. Refere-se à diferença técnicas de linguagem em ter acesso a um produto midiático por determinado meio de comunicação ou por outro. d) Mediação Situacional: Diz respeito à situação da recepção, ou seja, ver acompanhado ou ver sozinho, se acompanhado, por quantas pessoas, ver na tv ou na rádio, o estado de ânimos do receptor na hora da recepção, a vontade, etc; e) Mediação de Referência: Esta se refere a características do receptor, como a idade, gênero, etnia, classe social, entre outros.

\section{A recepção}

A pesquisa foi executada da seguinte maneira: primeiramente foram entrevistados os dez participantes e feitas as perguntas: nome, idade, escolaridade, profissão, renda familiar, visão política, religião e quais os meios e veículos em que se informa. Em seguida, foi reproduzida a reportagem do Jornal Nacional, que foi ao ar no dia 12 de junho de 2000 (dia do seqüestro do ônibus). Então foram feitas as seguintes perguntas:

1. De forma geral, como você vê as coberturas nesse tipo de caso (ônibus 174)? 2. Você tinha conhecimento desse caso (ônibus 174)? 3. Qual a sensação/sentimento que a reportagem te passa? 4. Qual a ideia/mensagem por trás da reportagem? 5. O tratamento dado ao caso pela reportagem foi adequado?6: Qual a sua opinião sobre a postura da imprensa, do assaltante e da polícia? 7. Você acha que a cobertura do caso foi isenta ou apresenta um lado? Caso apresente algum lado, qual é? 8. Quanto a informações sobre o assaltante (nome, trajetória de vida, etc), você acha que poderiam ter ganhado espaço na reportagem, a fim de contextualizar? 9. Quanto à profundidade da matéria, você acha que foi adequada?

Após respondidas as perguntas, a fim de apresentar o contexto do acontecimento, apresentando a vida do sequestrador, condições carcerárias do Brasil, situação dos meninos de rua e motivações da polícia, foram exibidos 


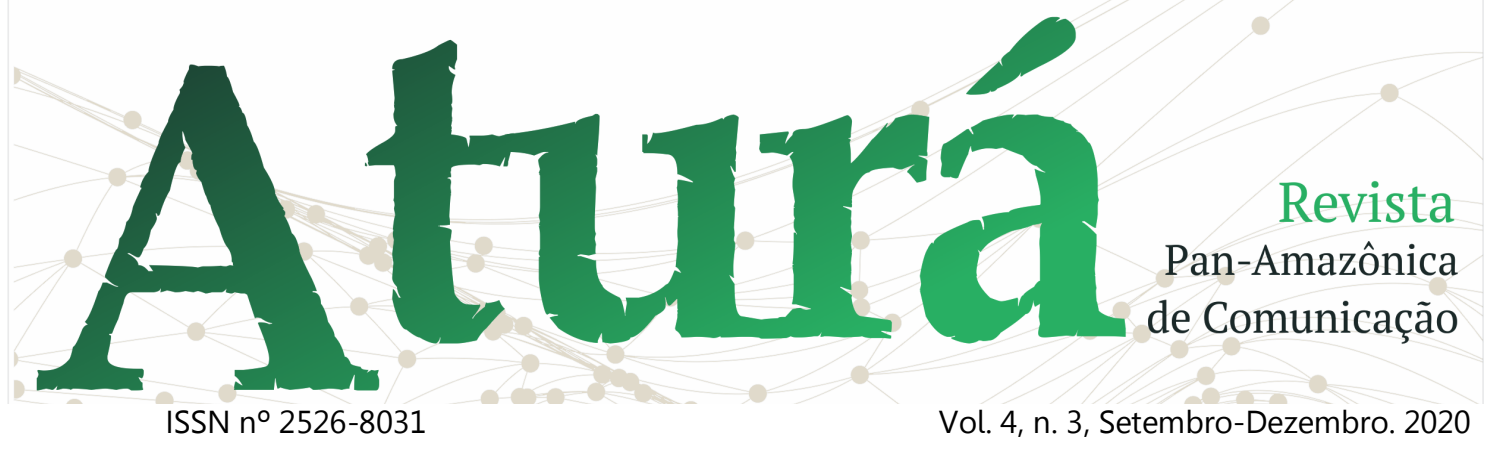

trechos do documentário "Ônibus 174", de José Padilha, o qual retrata todos esses aspectos. Em seguida, foram feitas algumas das perguntas acima citadas (de 3 a 9) novamente, com a finalidade de entender se ocorreria uma mudança em relação à recepção da primeira reportagem.

Entre os participantes, sete tinham conhecimento do caso e três não tinham ou não lembravam (pergunta número 2). É importante destacar que uma das participantes, Nathália, já tinha conhecimento do contexto no qual se passava o caso.

Traremos, no primeiro momento, as respostas da pergunta número $1 \mathrm{e}$, na sequência, de 3 a 9 , já fazendo o contraponto entre a primeira resposta (após assistir a reportagem) e a segunda (após assistir os trechos do documentário). Os perfis dos entrevistados serão trazidos ao longo das falas, em notas de rodapé.

Quando questionada sobre como vê as coberturas desse tipo de caso (pergunta 1), Adelia ${ }^{9}$ coloca que acha que exageram um pouco, e completa: "fazem sensacionalismo". Ernesto ${ }^{10}$ e Fabiana ${ }^{11}$, indo na mesma direção, também fazem menção ao uso do sensacionalismo, assim como Elen ${ }^{12}$, que coloca que muitas vezes faltam os direitos humanos. Ana Beatriz ${ }^{13}$ afirma que "Eles [os jornalistas] dão mais ênfase nessas coberturas negativas. Ficam repetindo muito. Parece que a gente está lá no meio". João $\mathrm{J}^{14}$, diz

\footnotetext{
${ }^{9}$ Adelia, 78 anos, ensino fundamental incompleto, renda familiar de um até três salários mínimos, católica. Quanto à visão política, considera-se de centro, pois diz ver os erros da esquerda e da direita. Informa-se pela televisão (Globo e Band) e por jornal impresso (Diário da Manhã e Diário Popular).

10 Ernesto, 49 anos, ensino técnico completo, eletrotécnico, renda familiar de cinco a dez salários mínimos, sem religião e de esquerda. Informa-se pela televisão (Globo e Band), impresso e internet (Zero Hora e Diário Popular).

11 Fabiana, 22 anos, ensino superior incompleto, estudante, renda familiar acima de dez salários mínimos, católica. Quanto à visão política, se diz de esquerda. Informa-se por jornais (Zero Hora) e internet (Carta Capital, Pública, Veja e El País).

${ }^{12}$ Elen, 43 anos, pós-graduada em educação infantil, professora do ensino fundamental, renda familiar de cinco a dez salários mínimos, espírita e considera-se de esquerda. Informa-se pela televisão (Globo), internet (G1, Mídia Ninja, site do Diário Popular e site da Espaço FM).

${ }^{13}$ Ana Beatriz, 59 anos, pós-graduada em artes visuais, professora aposentada, renda familiar de cinco a dez salários mínimos, católica. Quando a visão política, considera-se de centro-esquerda. Informa-se pela televisão (Globo News), internet (portal da Zero Hora) e jornal impresso (Diário Popular e Zero Hora).

14 João J, 40 anos, ensino superior incompleto (estudante de Ciências Sociais), eletrotécnico, renda familiar de três a cinco salários mínimos, agnóstico, e considera-se de esquerda (socialista). Informa-se por
} 


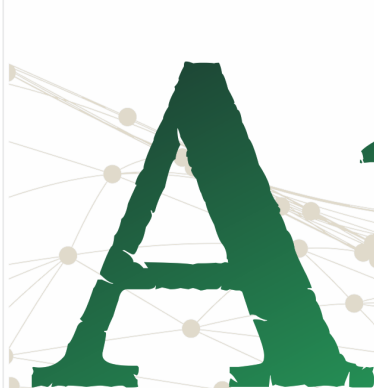

ISSN n² 2526-8031

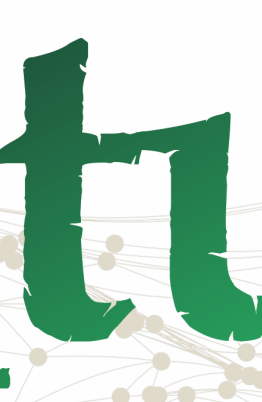

. Ira

Vol. 4, n. 3, S
Revista

Pan-Amazônica

de Comunicação que percebe uma tentativa de prender a atenção do telespectador, além de um pré-julgamento por parte dos jornalistas envolvidos. Eduardo ${ }^{15}$ aponta que a imprensa tem a tendência de mostrar esse tipo de caso desumanizando a pessoa que cometeu o delito e que, além disso, a forma como é mostrada a matéria direciona o olhar e interpretação do espectador. Já Hiago ${ }^{16}$ diz que geralmente vê algo bem superficial referente ao ocorrido. Nathália ${ }^{17}$, observando por este mesmo ponto, coloca que são superficiais, pois considera este tipo de caso muito complexo. Indo por outro lado, João ${ }^{18}$ conta que considera esse tipo de

jornal impresso, internet, televisão, rádio, dizendo manter seu senso crítico, questionando para que interesses servem aquela informação

15 Eduardo, 29 anos, pós-graduando, Diretor de Arte, renda de três a cinco salários mínimos, sem religião e de esquerda. Informa-se pela internet, principalmente pelo El Pais Brasil.

${ }^{16}$ Hiago, 22 anos, ensino superior incompleto, técnico em informática, renda familiar de cinco a dez salários mínimos, católico e considera-se de centro-direita. Informa-se pela internet (G1 e Uol notícias).

17 Nathália, 20 anos, ensino superior incompleto, estudante, renda familiar acima de 10 salários mínimos, espírita e se considera de centro-esquerda. Informa-se pela internet (G1, Folha de São Paulo e Mídia Ninja).

18 João, 82 anos, ensino técnico completo, aposentado, renda familiar de um a três salários mínimos, católico e de centro-esquerda. Informa-se pela televisão (Band e Globo) e jornais impressos (Diário Popular e Diário da Manhã). coberturas bem esclarecidas e acrescenta:"Eles fazem tudo que podem para informar bem".

3: Qual a sensação/sentimento que a reportagem te passa?

Hiago, após assistir a exibição da reportagem aponta que o sequestrador é mais um dos que deveriam estar mortos e que sente tristeza pelo ocorrido com a vítima. No segundo momento, após assistir a contextualização do caso através dos trechos do documentário, coloca agora que sente "angústia, desconforto por tudo que o Sandro passou e ver porque realmente isso ocorreu".

Fabiana, no primeiro momento, diz que a reportagem traz a sensação de medo e de violência extrema. No segundo, aponta que a reportagem traz o "sentimento de como os atos de violência nada mais são do que reflexos de uma trajetória de vida e de mazelas sociais".

Adélia, após assistir a reportagem caracteriza o sentimento como "um horror". No segundo momento aponta: "eu sinto que ele era vítima da própria sociedade". 


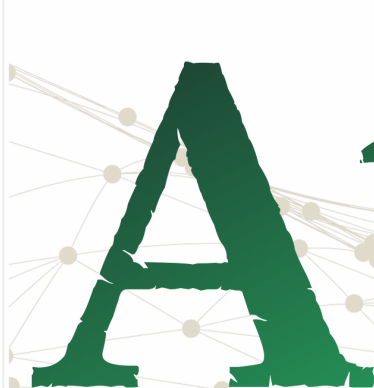

ISSN n² 2526-8031

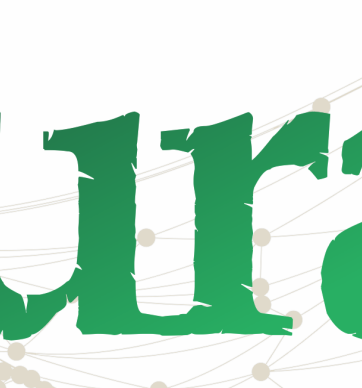

Vol. 4, n. 3, Setembro-Dezembro. 2020
Elen conta que sentiu angústia após a transmissão da reportagem. Após a contextualização, Elen coloca que o sentimento é de injustiça, impotência, pelo fato "da sociedade não conseguir enxergar os 'Sandros'".

Por fim, Ana Beatriz, num primeiro momento, coloca que a sensação é de insegurança "de um mundo em que a educação e a saúde são muito desiguais. Então estamos reféns das pessoas que não tem os direitos iguais aos nossos". No segundo momento aponta:

"A gente vê que a sociedade fica achando que ele é o bandido, e na verdade ele é uma grande vítima da sociedade, desde que nasceu. A gente vê que todo mundo quer que os guardadores de carro, meninos de rua, desapareçam, que eles morram, ninguém se preocupa com eles. Eles são considerados lixo da sociedade, e esse lixo tem que ser posto fora, é isso que a sociedade vê. Nós todos somos culpados pela história dele".

4: Qual a ideia/mensagem por trás da reportagem?

Fabiana, após assistir à
reportagem, aponta que a
ideia/mensagem por trás da reportagem seria "mostrar a insegurança vivida nas cidades e a violência cotidiana". No segundo momento, após assistir os trechos do documentário, coloca que

"A ideia principal é mostrar a violência
pela violência, sem contextualizar em
âmbito social, humano e psicológico o ato
ocorrido no ônibus 174. Não dar ao
'assaltante' (Sandro) um nome e nem
mostrar sua história não o 'torna
concreto', e sim apenas um 'personagem
responsável' por um ato de violência. O
ser individual é representado como um
'tipo social', o que corrobora para as
ideias de discriminação".

$\mathrm{Na}$ opinião de João J, a ideia/mensagem, no primeiro momento, é "a julgar pela designação do jovem envolvido (bandido, assaltante) é que a polícia cumpriu seu papel, afinal 'bandido bom é bandido morto" como parte da imprensa e a direita canalha vivem repetindo". Após assistir a contextualização do caso, aponta que a mensagem é "de que a ação do bandido/assaltante era uma violência gratuita e uma agressão à sociedade".

Adélia, no primeiro momento, indica que a ideia é mostrar que "os ladrões estão tão audaciosos que vão em qualquer lugar, falam que vão matar, e não matam". E conclui o seu raciocínio afirmando "Então eu acho que a polícia fez bem em eliminar. Menos um". No 


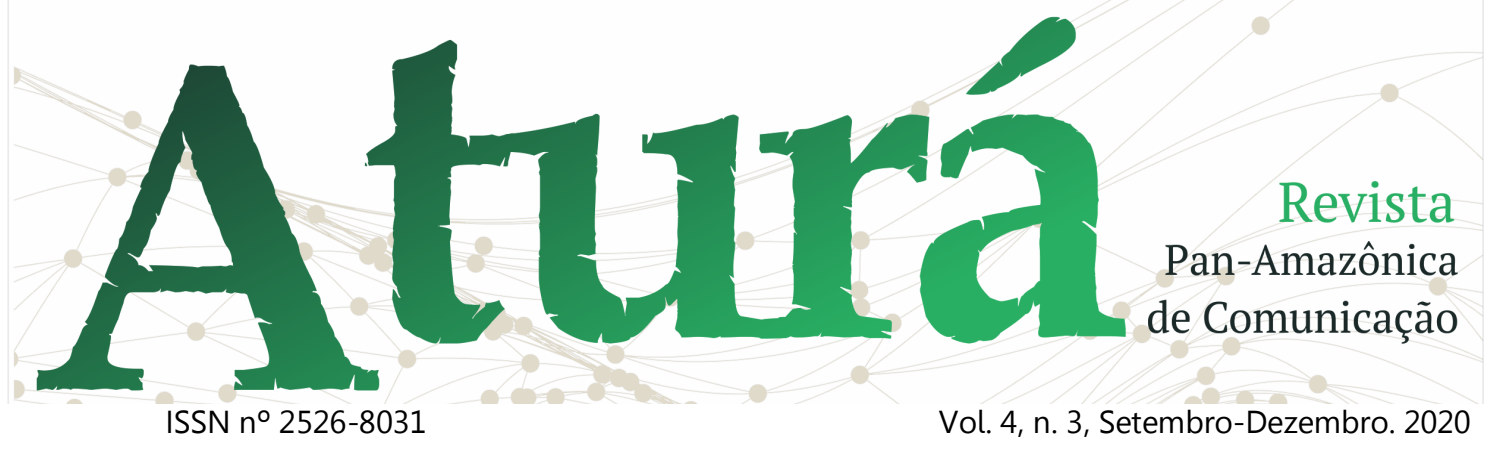

segundo momento, não soube $\circ$ que responder.

5: O tratamento dado ao caso pela reportagem foi adequado?

Após assistir a reportagem, João responde que acredita que $o$ tratamento dado pela matéria é adequada. Após os trechos do documentário, aponta que "não. Acho que faltou amor. Faltou tratamento humano".

Elen, no primeiro momento, frisaa questão da brutalidade e da vontade de chocar o público. Após os trechos do documentário aponta que "eles colocaram um vilão. Como se não existisse o outro lado da história. Não levaram o contexto de tudo. Levaram como fato isolado".

João J, após a reportagem, coloca que houvera um julgamento, um juízo de valor. Na sequência, após os trechos do documentário, acrescenta que este préjulgamento ocorreu descolado do contexto social das vítimas.

Ernesto, após a entrevista ser transmitida, aponta: "Acho que não foi adequado, pois deixaram de ver o lado do criminoso. Foi completamente parcial".

$\mathrm{Na}$ sequência, no segundo momento, coloca que mostrou apenas o lado "hipócrita da sociedade dominante".

6: Qual a sua opinião sobre a postura da imprensa, do assaltante e da polícia?

Fabiana, após assistir a reportagem, aponta que a reportagem feita pela imprensa foi "baseada nas emoções". Sobre a postura do assaltante, como uma estudante de medicina, traz que:

"como eu tenho uma visão mais voltada
pra área da saúde, tive a sensação de que
o assaltante talvez tivesse alguma
patologia psiquiátrica ou talvez estivesse
sob o efeito de alguma substância. Acho
difícil achar uma justificativa mais objetiva
pra uma ação aparentemente não
planejada e extremamente violenta (além
da parte que ele diz que tá dominado
pelo diabo)".

Quanto à postura da polícia, conta que não sabe se abordagem final (atirar no assaltante) era realmente necessária para garantir a segurança da refém. Já no segundo momento, Fabiana coloca que "na reportagem retratada pela Globo, apenas se vê de forma rasa uma ação, na qual nenhum dado é apresentado e o que é retratado é um pânico que, possivelmente, foi muito menor que o 


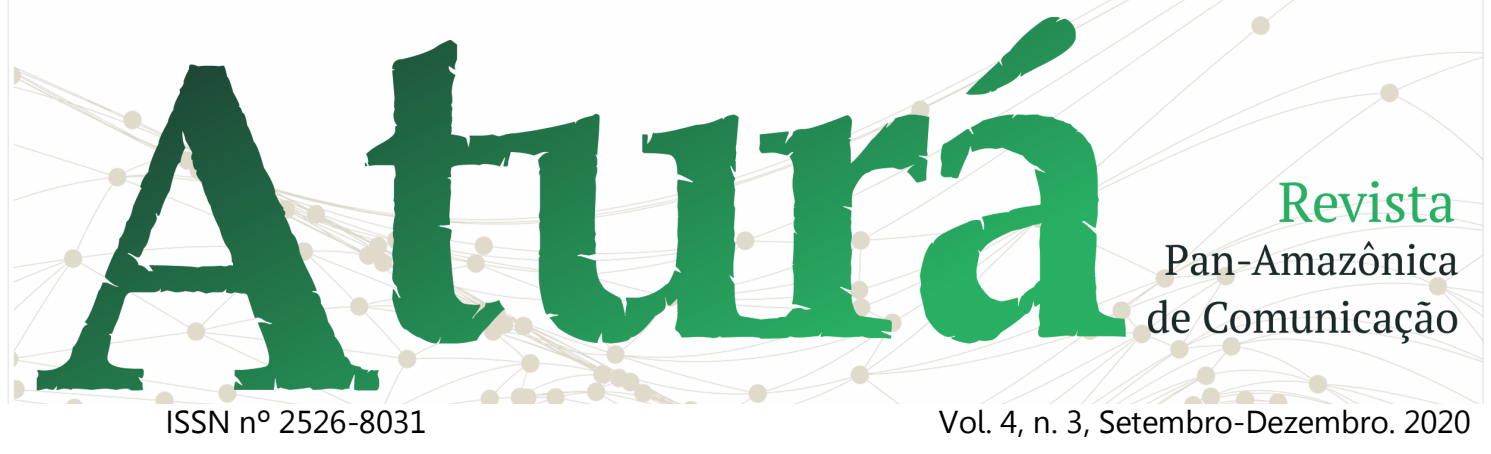

apresentado". Quanto ao assaltante, que anteriormente apontara alguma patologia psiquiátrica ou uso de alguma substância, agora salienta que este era um

"membro da sociedade que sofre diariamente pequenas e grandes violências, seja na privação de necessidades básicas, seja na punição desumana dada nos presídios (que deveriam "recuperar" o cidadão). Quando crianças ficam expostas ao ambiente da rua, sem segurança e sem as condições básicas, soa hipócrita dizer que 'é bandido'. Mais uma vez, um ato que claramente não foi planejado e dotado de uma violência (aparentemente extrema, como mostrado na outra reportagem) não tem outra tradução a não ser um desespero e uma resignação enorme que explodiu"

7: Você acha que a cobertura do caso foi isenta ou apresenta um lado? Caso apresente algum lado, qual é?

Adelia aponta, no primeiro momento, que a reportagem teria sido isenta. Após assistir os trechos do documentário, acredita que esta "apresentou mais o lado da polícia".

Na opinião de Ana Beatriz, após no primeiro momento, a reportagem foi isenta. No segundo momento, Ana Beatriz aponta que "no momento, não é que a Globo errou ou acertou. Estava mostrando o que estava acontecendo. Pra sociedade, tem $\mathrm{o}$ bandido e tem as vítimas, e no momento é o que estava mostrando".

João J coloca, após assistir o primeiro vídeo, que a reportagem apresentava o lado da força repressora. No segundo momento, João J aponta que apresenta o "o lado dos 'homens de bem', da sociedade, da 'lei'. É uma tentativa de justificar a ação truculenta do Estado".

Já Elen, coloca, após assistir a reportagem, que "apresenta o lado da polícia. Prevalece a visão do lado mais forte da sociedade". No segundo momento, Elen aponta que "quis mostrar que bandido é bandido, não interessa. Quis mostrar que bandido bom é bandido morto, como os 'cidadãos de bem' falam".

8: Quanto a informações sobre o assaltante (nome, trajetória de vida, etc), você acha que poderiam ter ganhado espaço na reportagem, a fim de contextualizar? ${ }^{19}$

\footnotetext{
19 Todos os participantes, desde o início, apontaram que seria importante.
} 


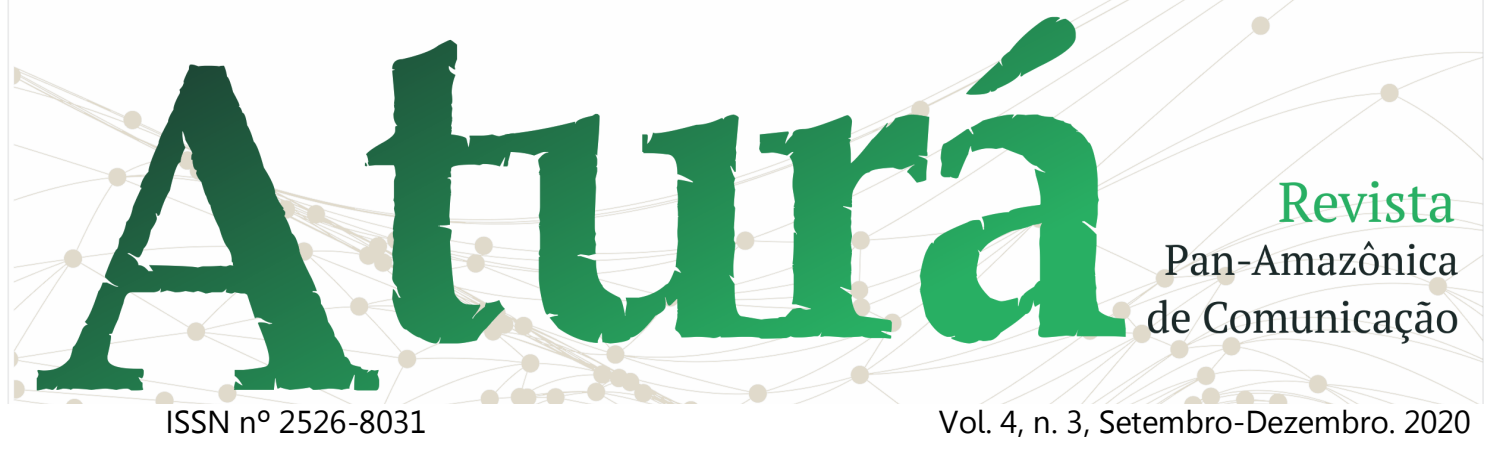

Ana Beatriz aponta que seria importante para ver por que aquela pessoa chegou até ali. No segundo momento salienta que "Acho que a televisão tinha que passar toda essa história para ensinar a população brasileira e mundial que uma pessoa chega nesse ponto pelo que ela passou. Olha essa história da morte dos amigos na Candelária, a morte da mãe...".

João J coloca que é evidente que essas informações seriam importantes, mas que, no entanto, "preferiram optar por chamá-lo de bandido, de assaltante e criminoso". No segundo momento, João J diz que

"em momento algum a matéria da Globo fala em SANDRO. Em momento algum trata das tragédias do passado de Sandro. Em momento algum diz que o menino viu a mãe ser assassinada (e depois os colegas na Candelária). Não questiona se teve acesso à acompanhamento psicológico por parte do Estado. Para ele (Sandro) a face do Estado foi a da ação policial, da violência, da truculência, etc".

Para Fabiana, "contextualizar a vida do assaltante é essencial para entender uma possível justificativa para a ação e se realmente possui uma justificativa". No segundo momento, a estudante de medicina aponta que algumas perspectivas referentes ao caso deveriam ter sido mostrados:

"o assassinato da mãe de Sandro, a qual ele presenciou, mas acho que principalmente o massacre de candelária. Já tendo sua mãe assassinada, Sandro achou nas ruas e nos amigos que conviviam com ele na Candelária uma nova família. A partir do momento que o aparato do Estado (que deveria proteger e ajudar todos os cidadãos, independe de qualquer condição) pratica um ato covarde e de violência extrema e mata mais de 10 crianças, o mínimo que se espera é uma revolta imensa que é projetada naquilo que Sandro nunca se sentiu parte: da sociedade"

Elen aponta que a importância dessas informações estaria em as pessoas não verem Sandro com tanta brutalidade. Após ver os trechos do documentário, diz que seria importante porque "eles desrespeitaram completamente $O$ ser humano (Sandro). Não levaram em conta o ser humano, sua trajetória, sua história de vida, não levaram em conta nada. Ninguém ia fazer aquilo se não tivesse um motivo muito forte".

9: Quanto à profundidade da matéria, você acha que foi adequada?

João afirma, no primeiro momento, que não teria mais o que aprofundar. No segundo momento, João aponta que "a reportagem do Jornal Nacional 


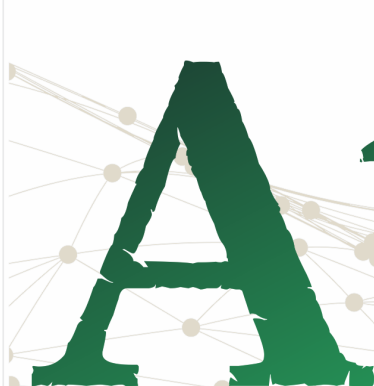

ISSN n² 2526-8031

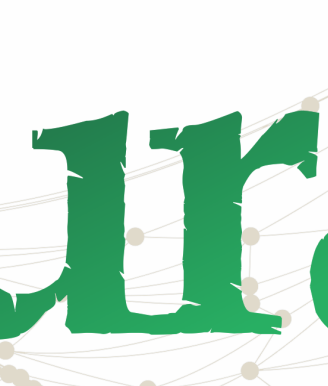

Vol. 4, n. 3, Setembro-Dezembro. 2020 apresentasse algumas das informações vistas no segundo vídeo seria bem melhor".

João J caracteriza a reportagem, após assisti-la, como "horrorosa, tendenciosa e inútil". No segundo momento, João J só firma mais seu posicionamento, colocando-a como "inútil e beirando a irresponsabilidade. Não teve a intenção de informar. Matérias como essa servem de base à ideia do bandido bom é banido morto"

Eduardo, aponta que a matéria fora muito pouco profunda, e que deixara muitas lacunas. Após a contextualização, conta que acredita que a "reportagem é profunda como um pires, mostrando o fato isolado sem mostrar que o caso é um produto da nossa sociedade e omitindo o contexto que muitos brasileiros são submetidos diariamente, que é a verdadeira causa da sociedade violenta que vivemos nos tempos atuais".

Ana Beatriz, quando questionada pela primeira vez, afirma que profundidade não é adequada. $\mathrm{Na}$ segunda, Ana Beatriz coloca que "faltou a contextualização, mas acho que eles estavam gravando 0 que estava acontecendo, porque depois que acontece que a pessoa consegue refletir. $\mathrm{Na}$ hora, só se vê o acontecimento, ele fazendo os reféns...".

Por fim, Elenressaltou, no primeiro momento, que a ênfase dada teria sido muita: "deixaram de noticiar outros assuntos, só pra chamar a atenção do público e ganhar audiência". Na sequência, aponta que "não teve profundidade a reportagem. Mostraram como um caso isolado e não levaram as circunstâncias".

\section{As constatações}

Através desse estudo, podemos ver as multimediações, trazidas por Orozco Gómez atuando em vários momentos. $\mathrm{A}$ posição política dos participantes, por exemplo, foi de extrema importância na interpretação do caso num primeiro momento. A opinião da grande maioria dos entrevistados que se colocam como de esquerda, sobre a sensação e sentimento passado pela reportagem, por exemplo, destoa completamente da opinião do entrevistado que se diz de 


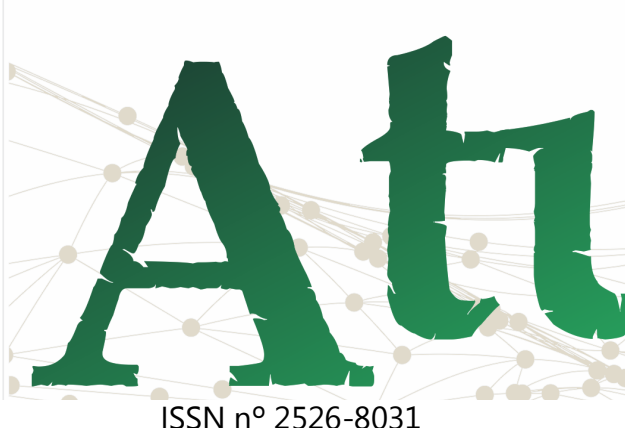

ISSN n² 2526-8031

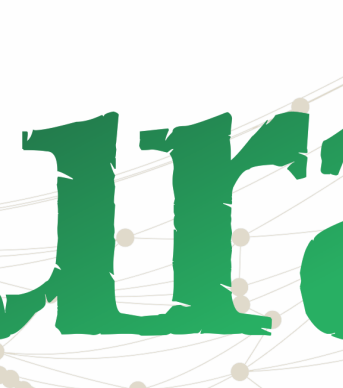

Vol. 4, n. 3, Setembro-Dezembro. 2020 centro-direita e da entrevistada que se diz de centro. Além disso, podemos notar que, num primeiro momento, os entrevistados de maior idade (mediação de referência) concordaram quanto a "isenção" da notícia, apontando que a reportagem não apresentava um lado. Podemos observar que a renda familiar afetou pouco ou nada nas opiniões e que a religião (mediação institucional) só afetou, a princípio, em um momento, quando uma das entrevistadas, católica dedicada, usa a seguinte frase: "quando a pessoa se entrega pras drogas o diabo toma conta mesmo". A mediação institucional se mostra novamente quando a entrevistada, estudante de medicina, coloca que teve "a sensação de que $\mathrm{o}$ assaltante talvez tivesse alguma patologia psiquiátrica ou talvez estivesse sob o efeito de alguma substância".

Quanto às mudanças de opinião, o fato que chama atenção é que, após a exibição do segundo vídeo, o qual contextualizou muitos fatores referentes ao caso, os entrevistados que usaram frases como "mais um de muitos que mereceriam estar mortos", e "eu acho que a polícia fez bem em eliminar. Menos um" demonstraram certa empatia por Sandro, e entenderam a raiz do problema, dizendo sentir "angústia, desconforto por tudo que o Sandro passou e ver o porquê realmente isso ocorreu", e "eu sinto que ele era vítima da própria sociedade". Quanto aos participantes que demonstraram desde o princípio empatia por Sandro, o sentimento só se manteve ou se intensificou na segunda parte da entrevista.

\section{Considerações finais}

O estudo de recepção mostrou que, no momento que a notícia foi contextualizada a partir dos trechos do documentário, mostrando muitos dos "comos" e "porquês" (os quais muitas vezes, as reportagens de televisão omitem), até quem, de início, acreditava que Sandro deveria morrer, entendeu os porquês e compreendeu que Sandro é fruto do sistema e das condições que este proporciona. $O$ fato de a grande maioria dos receptores ter apontado 0 sensacionalismo, e o destacado como uma qualidade negativa, a fim de 


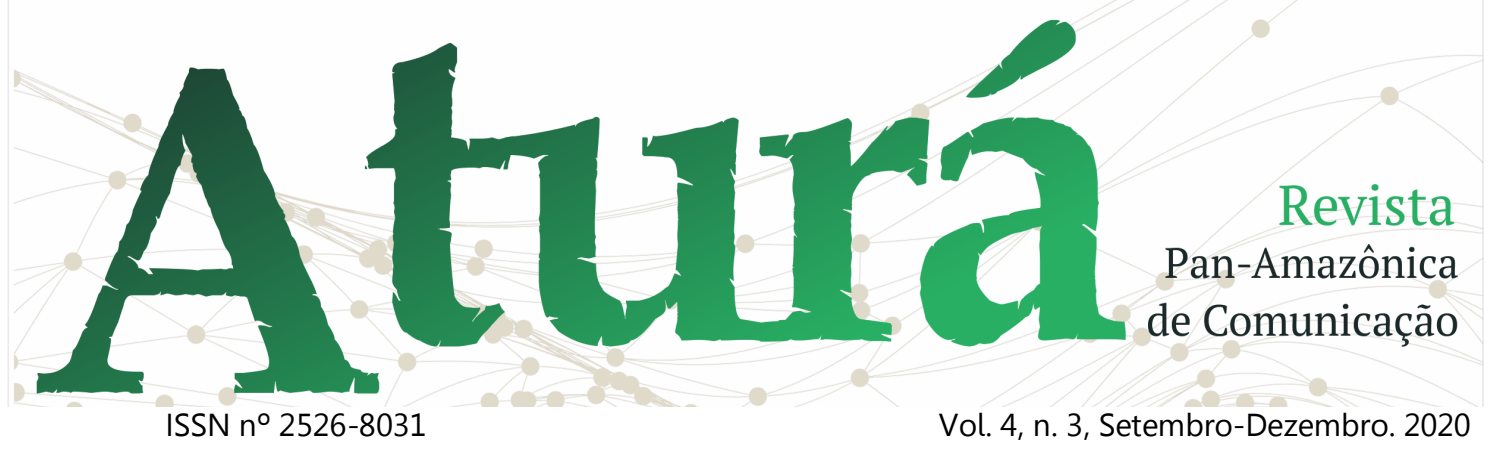

aumentar a audiência em detrimento da qualidade da notícia também é um fator a ser destacado.

Podemos entender que o público já não é mais o mesmo, que entende as técnicas para atingir fins mercadológicos utilizadas e que, em muitos casos, não aprovam mais isso. Destacamos, ainda, que, quando apresentada uma possibilidade de uma maior contextualização da notícia, todos os receptores que participaram, independentemente de qualquer mediação, disseram acreditar ser importante.

Por fim, concluímos que parte dos receptores percebe que o telejornalismo, pelo menos no caso apresentado, está a favor de uma determinada forma de poder e não aprova mais isso. $\mathrm{O}$ telejornalismo, o qual manteve seu formato por décadas, precisa ser repensado e aprimorado. Conforme os dados obtidos no estudo de recepção, podemos concluir que dar preferência a características implantadas por questões mercadológicas e de estrutura, em detrimento da qualidade e complexidade 